\title{
FAKTOR-FAKTOR KECURANGAN AKUNTANSI DI PEMERINTAH DAERAH DAN PERAN ETIKA ISLAM DALAM PENCEGAHANNYA
}

\author{
Dani Kusumastutii \\ danikusumastutigo@gmail.com \\ Fakultas Ekonomi dan Bisnis IAIN Purwokerto
}

\section{Abstract}

Purpose - Corruption in local government is becoming increasingly prevalent. This has become an irony amid the vigorous development in the era of regional autonomy. To deal with this problem, this study is aimed to identify the factors of fraud in the local governments of Indonesia and to investigate whether the application of Islamic ethic can prevent accounting fraud.

Design/methodology/approach - To achieve this goal, this study collects and compares the results of various quantitative empirical studies in various local governments throughout Indonesia that have been carried out in the past three years (2015-2017). The data will be synthesized and conclusions drawn in this study to answer research questions. The data is obtained in journals traced in several electronic media such as digital libraries, internet or library journal collections. The keywords used for search are: factors, accounting fraud, fraud, prevention and local government.

Findings - The results provide evidences that indicate that accounting fraud in local goverments of Indonesia is significantly influenced by factors explained in Fraud theory. It is also proved from empirical studies that the implementation of Islamic ethic is useful to prevent fraud within local goverments in Indonesia.

Research limitations/implications -The result of the paper contribute to the literature in understanding of how to prevent accounting fraud especially within the local governments in Indonesia by developing approaches based on Islamic ethics.

Originality/value - Findings are useful for policy makers and local goverments to handle accounting fraud cases and enhance their accounting fraud prevention system by applying Islamic ethics.

Keywords fraud, local goverment, Islamic ethics.

\section{el-JIZYA}

Vol. 7 No. 1 Januari-Juni 2019 


\section{A. PENDAHULUAN}

Tuntutan reformasi sektor publik telah dijawab pemerintah dan Dewan Perwakilan Rakyat (DPR) dengan mengeluarkan UU no. 33 tahun 2004 tentang Penyetaraan Keuangan antara pemerintah pusat dan daerah dan UU No. 23 tahun 2014 tentang Pemerintah Daerah. Undang-undang tersebut memuat kebijakan desentralisasi fiskal dan otonomi daerah dalam sistem pemerintahan yang menjadi momentum pembangunan yang lebih berkeadilan bagi daerah. Adanya reformasi pemerintahan berimplikasi terhadap menguatnya tuntutan akuntabilitas atas lembaga-lembaga publik, baik di pusat maupun daerah. Akuntabilitas publik merupakan "kewajiban untuk memberikan pertanggungjawaban serta menerangkan kinerja dan tindakan seseorang, badan hukum atau pimpinan organisasi kepada pihak yang lain yang memiliki hak dan kewajiban untuk meminta pertanggungjawaban dan keterangan. ${ }^{1}$

Adanya kewenangan daerah yang lebih luas dalam pengelolaan keuangannya dalam kenyataanya juga memberi ruang yang makin terbuka bagi tindak kecurangan berupa korupsi oleh oknum di pemerintahan daerah. Menurut survey ACFE Indonesia, korupsi merupakan bentuk kecurangan yang paling banyak terjadi di Indonesia. ${ }^{2}$ Hasil riset Indonesian Corruption Watch (ICW) mengungkap dari tahun ke tahun korupsi di Indonesia mengalami tren yang meningkat. Bagian terbesar terjadi di lingkup pemerintah daerah yang mencapai 77 persen. $^{3}$

Sejalan dengan ICW, penelitian Fakultas Ekonomi dan Bisnis Universitas Gadjah Mada juga mencatat temuan serupa. Tercatat pada 20012009 Mahkamah Agung (MA) telah memutus kasus korupsi sejumlah 549 kasus. Di periode 2014-2015 jumlahnya meningkat menjadi sebanyak 803 kasus. Jika diakumulasi semenjak 2001 hingga 2015, ada sejumlah 2.321 kasus korupsi yang telah diputus oleh MA pada tingkat kasasi maupun

\footnotetext{
${ }^{1}$ Abdul Halim dan kawan-kawan, Akuntansi Sektor Publik Akuntansi Keuangan Daerah, Edisi 4, Jakarta: Penerbit Salemba Empat, 2012, hlm. 20.

2Indonesia Chapter ACFE, 'Survai Fraud Indonesia 2016', ACFE Association of Certified Fraud Examiners, 2016, hlm. 13.

${ }^{3}$ https://kominfo.go.id/index.php/content/detail/6547/Potret-Buram-Korupsi-Indonesia/0/infografis, diunduh pada 23 Maret 2018.
} 
peninjauan kembali. Jumlah ini meningkat tajam dibanding data pada 20012009 yang jumlahnya 549 kasus. ${ }^{4}$

Buramnya potret korupsi di Indonesia dapat tergambar dari indeks persepsi korupsi pelaku usaha terhadap pelayanan publik. Berdasarkan indeks persepsi korupsi tahun 2017 yang dirilis Transparency International, Indonesia berada di peringkat ke-96 dengan nilai 37. ${ }^{5}$ Indeks ini belum bergeser dari angka yang sama di tahun 2016. Kecenderungan ini banyak terjadi di negaranegara lainnya yang membuat Transparency International menyimpulkan belum ada perkembangan yang nyata dari negara-negara ini untuk mengakhiri korupsi. ${ }^{6}$ Menurut ICW, tindak korupsi yang banyak terjadi dilakukan dalam bentuk penggelapan dengan memanipulasi pencatatan dan penghilangan dokumen, proyek fiktif, penyalahgunaan anggaran, mark up, penyalahgunaan wewenang, laporan fiktif dan suap/gratifikasi. ${ }^{7}$

Fenomena meningkatnya korupsi di pemerintahan daerah menjadi suatu ironi di tengah derasnya arus pembangunan daerah di era otonomi. Guna menangani persoalan tersebut diperlukan studi untuk mengidentifikasi faktor-faktor apakah yang mempengaruhi kecurangan akuntansi di pemerintah daerah? Apakah ada kesamaan faktor-faktor tersebut di berbagai pemerintahan daerah? Faktor-faktor apa yang dapat mencegah kecurangan akuntansi di pemerintah daerah? Apakah penerapan etika Islam dapat mencegah kecurangan akuntansi ?

Makalah ini disusun untuk membahas permasalahan tersebut berdasarkan kerangka teori mengenai kecurangan akuntansi dan teori etika serta studi-studi empiris yang mengungkap faktor-faktor kecurangan akuntansi di berbagai pemerintah daerah. Tujuan penulisan artikel ini adalah memperoleh pemahaman tentang cara pencegahan kecurangan akuntansi khususnya dalam lingkup pemerintah daerah dengan mengembangkan pendekatan berdasarkan etika Islam. Signifikansi dari studi ini secara teoretis

${ }^{4}$ http://news.liputan6.com/read/2477341/kasus-korupsi-di-indonesia-menggila, diakses 11 Maret 2018.

5Indeks persepsi korupsi dari Transparency International menggunakan skala 0-100. Nilai nol artinya paling tidak korup, sedangkan nilai seratus berarti paling bersih.

${ }^{6}$ https://www.transparency.org/news/feature/corruption_perceptions_index_2017, diakses 20 Maret 2018.

${ }^{7}$ https://kominfo.go.id/index.php/content/detail/6547/Potret-Buram-Korupsi-Indonesia/0/infografis, diunduh pada 23 Maret 2018. 
adalah memberikan bukti empiris terkait teori Fraud dan etika (Islam) terkait perilaku kecurangan yang terjadi dalam lingkup pemerintahan daerah dan penanganannya. Bagi pengambil kebijakan termasuk pemerintah daerah hasil studi ini diharapkan dapat berguna sebagai bahan evaluasi dan landasan pengambilan keputusan dan kebijakan terkait penanganan kecurangan akuntansi baik secara kuratif maupun preventif.

Sistematika penulisan makalah ini diawali dengan pendahuluan, dilanjutkan dengan kajian teori terkait. Bagian selanjutnya merupakan pembahasan yang berisikan paparan hasil-hasil penelitian empiris terdahulu yang yang relevan dengan permasalahan. Selanjutnya pada bagian akhir merupakan kesimpulan.

\section{B. KERANGKA TEORI}

\section{Kecurangan Akuntansi (Fraud)}

Kecurangan atau fraud merupakan istilah hukum yang diserap dalam ilmu akuntansi forensik. Kamus bahasa Indonesia karangan WJS Purwadarminta menerangkan kecurangan sebagai 'tidak jujur', 'tidak lurus hati', 'tidak adil' dan keculasan. ${ }^{8}$ Webster's New World Dictionary mendefinisikan fraud sebagai suatu pembohongan atau penipuan (deception) yang dilakukan untuk kepentingan pribadi. Menurut Accociation of Certified Fraud Examiner (ACFE), menjelaskan kecurangan sebagai kebohongan yang disengaja guna mendapatkan keuntungan dari orang atau kelompok lain. ${ }^{9}$ The Institute of Internal Auditors (IIA) menjelaskan bahwa kecurangan merupakan pelanggaran hukum berupa penipuan, penyembunyian atau penyalahgunaan kepercayaan dengan maksud memperoleh keuntungan haram. ${ }^{10}$

ACFE mengkategorikan tindakan kecurangan di internal organisasi ke dalam 3 (tiga) tipe yakni: penyimpangan atas aset (asset missapropriation), pernyataan palsu atau salah (fraudulent statement) dan korupsi (corruption). Asset missapropriation adalah penyalahgunaan/pencurian aset atau harta organisasi atau pihak lain. Sedangkan fraudulent statement merupakan

\footnotetext{
${ }^{8}$ Soejono Karni, Auditing, Audit Khusus dan Audit Forensik, Jakarta: Lembaga Penerbit FE UI, 2000, hlm. 49.

${ }^{9}$ Karyono, Forensic Fraud, Yogyakarta: Penerbit ANDI, 2013, hlm. 3.

${ }^{10}$ Theodorus M. Tuanakotta, Audit Berbasis ISA, Jakarta: Salemba Empat, 2013, hlm. 28.
} 
tindakan menutupi kondisi keuangan yang sebenarnya dengan melakukan rekayasa keuangan (financial engineering) dalam penyajian laporan keuangan. Adapun korupsi dalam konteks kecurangan di organisasi dimaknai sebagai tindakan penyalahgunaan wewenang atau konflik kepentingan, penyuapan, penerimaan tidak sah/ilegal dan pemerasan secara ekonomi. ${ }^{11}$

James A. Hall menjelaskan dua tingkatan kecurangan berdasarkan pelakunya yaitu employee fraud dan management fraud. Employee fraud merupakan kecurangan yang dilakukan oleh pegawai suatu organisasi kerja yang mempunyai tujuan langsung merubah kas atau aset lain untuk keuntungan pribadi. Kecurangan karyawan biasanya melalui tiga tahap yaitu (1) mencuri aset yang, (2) merubah aset menjadi bentuk kas atau yang likuid (mudah ditukar), (3) menutupi kejahatan agar tidak terungkap atau menghindari deteksi. Management Fraud adalah kecurangan yang dilakukan oleh pihak manajemen atau pimpinan organisasi biasanya menggunakan laporan keuangan sarana untuk mencurangi pemegang kepentingan organisasinya. Kecurangan level manajemen mampu melampaui struktur pengendalian internal yang efektif mencegah fraud oleh karyawan. Oleh karena itu akan jauh lebih berbahaya dibandingkan fraud yang dilakukan karyawan karena lebih sulit terdeteksi, hingga terjadi kerugian parah atau kerusakan fatal di perusahaan. ${ }^{12}$

\section{Penyebab Kecurangan}

Donald R. Cressey dalam teorinya yang dikenal dengan Fraud Triangle menjelaskan 3 (tiga) faktor yang mendukung seseorang melakukan kecurangan yaitu tekanan atau insentif (pressure), kesempatan (opportunity) dan rasionalisasi (rationalization). ${ }^{13}$ Tekanan merujuk pada situasi yang mendorong seseorang bertindak curang baik yang berasal dari dalam ataupun diluar dirinya, yang bersifat finansial maupun nonfinansial seperti adanya masalah keuangan pribadi, tekanan gaya hidup dan target dari

\footnotetext{
${ }^{11}$ Theodorus M. Tuanakotta, Akuntansi Forensik dan Audit Investigatif, Jakarta: Lembaga Penerbit Fakultas Ekonomi Universitas Indonesia, 2007, hlm. 96-105.

${ }^{12}$ James A. Hall, 'Accounting Information Systems Seventh Edition', in South-Western Cengage Learning, 2011.

${ }^{13}$ Donald R. Cressey, 'Other People's Money: A Study in the Social Psychology of Embezzlement.', American Sociological Review, 1954, vol 19, no 3, pp.362-363.
} 
perusahaan/atasan. Kecurangan juga terjadi karena adanya kesempatan, yang timbul dari lemahnya pengendalian internal atau sistem tata kelola organisasi.

Rasionalisasi merupakan pembenaran yang menjadi alasan seseorang bertindak curang. ${ }^{14}$ Steve Albrecht mengganti faktor rasionalisasi dari teorifraud triangle milik Cressey dengan personal integrity, dimana kecurangan akan rendah manakala integritas personal tinggi. Sementara Wolfe dan Hermanson menambahkan satu faktor kecurangan berupa kemampuan (capability) seseorang untuk bertindak curang, sehingga penjelasannya dikenal dengan Fraud Diamond Theory. ${ }^{15}$ Dari beragam pemicu kecurangan keuangan, faktor Kesempatan merupakan faktor yang paling mungkin diminimalisir karena satu-satunya yang berasal dari luar diri pelaku.

\section{Kecurangan dalam Perspektif Islam}

Kecurangan merupakan perbuatan yang sangat tercela dan keji dalam pandangan Islam. Hal ini karena kecurangan menimbulkan akan merugikan banyak pihak dan mengancam keseimbangan kehidupan sosial ekonomi dan ekologi. Hal ini bertentangan dengan tujuan syariah Islam (maqashid al syariah) yang dimaksudkan untuk memelihara manusia dalam hal agama, jiwa, akal, keturunan dan hartanya. Oleh karena itu kecurangan dalam segala bentuknya harus dijauhi oleh para pelaku ekonomi dalam aktivitasnya.

Kecurangan khususnya berupa korupsi memiliki kedekatan arti

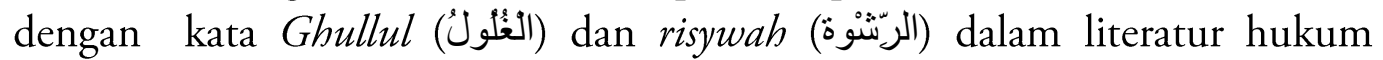
Islam. Ibnu Hajar al-Asqalani mendefinisikan ghullul sebagai 'apa saja yang diambil dari barang rampasan perang secara sembunyi-sembunyi sebelum pembagian'. ${ }^{16}$ Nash yang menjadi dalil pelarangan ghullul adalah Quran surat Ali Imran ayat $161,{ }^{17}$ dan hadits diantaranya dalam shahih Bukhari, kitab al-

\footnotetext{
${ }^{14} \mathrm{R}$ Abdullahi and N Mansor, 'Fraud Triangle Theory and Fraud Diamond Theory: Understanding the Convergent and Divergent For Future Research', International Journal of Academic Research in Accounting, Finance and Management Sciences, 2015, vol 5 No 4, pp.3-4.

${ }^{15}$ Rabi'u Abdullahi and Noorhayati Mansor, "Fraud Triangle Theory and........, hlm.5.

${ }^{16}$ Tulus Suryanto and Anip Dwi Saputro, Fraud Akuntansi dalam Perspektif Islam, Yogyakarta: Arti Bumi Intaran, 2016.

17 Terjemahnya: tidak mungkin seorang nabi berkhianat dalam urusan harga rampasan perang itu, maka pada hari kiamat ia akan datang membawa apa yang dikhianatkannya itu; kemudian tiap-
} 
Jihad wa al-Sa'ir nomor $2845,{ }^{18}$ dan dalam shahih Muslim, kitab al-Iman, nomor $165 .{ }^{19}$ Dalam hadits ghullul juga terjadi pada kasus pegawai/pejabat yang mengambil sesuatu di luar haknya yang diatur resmi sebagaimana dalam Sunan Abu Daud dalam kitab Al Kharaj Wal Imaroh wal Fa'i nomor hadits $2943,{ }^{20}$ dan menerima hadian dari pihak tertentu terkait tugasnya misalnya dalam Musnad Ahmad nomor hadits 22495.21

Bentuk lain dari korupsi adalah suap atau risywah. Suap merupakan suatu tawaran atau janji dari seseorang untuk memberikan sesuatu untuk mempengaruhi atau membujuk orang lain melakukan sesuatu yang tidak

tiap diri akan diberi pembalasan tentang apa yang ia kerjakan dengan (pembalasan) setimpal, sedang mereka tidak dianiaya.

${ }^{18}$ Terjemahnya: Ali ibn Abdillah telah menceritakan hadis kepada kami, Sufyan telah menceritakan kepada kami. Dari Amr, dari Salim ibn Abi Al-Ja'di, dari Abdullah ibn Umar berkata: bahwa pada rombongan Rasulullah saw, ...Ada seorang bernama Kirkirah yang mati di medan perang. Rasulullah saw. Bersabda: "dia masuk neraka". Para sahabat pun bergegas pergi menyelidiki perbekalan perangnya. Mereka mendapatkan mantel yang ia korup dari harta rampasan perang. (H.R. Bukhari).

${ }^{19}$ Terjemahnya: Zuhair ibn Harb telah menceritakan hadis kepadaku, Hasyim ibn Al-Qasim telah menceritakan hadis kepada kami, Iqrimah ibn Amr telah menceritakan hadis kepada kami. Ia berkata simak al Hanafi Abu Zumail telah bercerita kepadaku. Ia berkata Abdullah ibn Abbas telah menceritakan kepadaku. Umar ibn AL-Khattab menceritakan kepadaku bahwa ia berkata: ketika terjadi perang Khaibar beberapa sahabat Nabi berkata: "si Fulan mati syahid, si Fulan mati syahid. Hingga mereka berpapasan dengan seseorang. Mereka pun berkata: si Fulan mati syahid. Kemudian Rasulullah sawbersabda: Tidak begitu. Sungguh aku melihatnya di dalam neraka karena burdah (selimut atau aba'ah) mantel yang ia korup dari harta rampasan perang. Lalu Rasulullan saw. berkata: Wahai ibn al-Khattab, berangkatlah dan sampaikan kepada manusia bahwa tidak akan masuk surga selain orang-orang yang beriman." Maka aku keluar dan menyerukan kepada manusia: ingatlah, ingatlah sesungguhnya tidak masuk surga selain orang-orang yang beriman". (H.R. Muslim).

${ }^{20}$ Terjemahnya: Zaid bin Akhzam Abu Thalib telah menceritakan hadis kepada kami, Abu 'Ashim telah menceritakan kepada kami, dari Abd Al-Warits ibn Sa'id dari Husain al-Mu'alim, dari Abdullah ibn Buraidah, dari bapaknya, dari Nabi...Beliau bersabda: "siapa saja yang telah kami angkat untuk mengerjakan suatu pekerjaan/jabatan kemudian kami telah memberikan gaji, maka sesuatu yang diterima di luar gajinya yang sah adalah ghulul (korupsi)."(H.R. Abu Daud).

${ }^{21}$ Ishaq ibn Isa telah menceritakan hadis kepada kami, Isma'il ibn Ayyasy telah menceritakan hadis kepada kami, dari Yahya ibn Sa'id, dari Urwah ibn al-Zubair, dari Abi Humaid al-Sa'idi, ia berkata bahwa Rasulullah saw. ....Bersabda: "Hadiah yang diterima para pejabat/pemegang kebijakan adalah ghulul (korupsi)."(H.R. Ibn Hanbal). 
dibenarkan secara hukum untuk kepentingannya. ${ }^{22}$ Perbedaan dengan ghullul adalah jika ghullul dilakukan oleh satu pihak yang aktif, risywah dilakukan oleh dua pihak yang sama-sama aktif dan sama-sama berkepentingan. Rasulullah saw. Melaknat penyuap, penerima suap dan perantaranya, yaitu orang yang menghubungkan antara keduanya sebagaimana termuat dalam hadits yang diriwayatkan Ahmad bin Hanbal. ${ }^{23}$ Ulama sepakat bahwa praktik suap terhadap pegawai atau pejabat dilarang dalam Islam. ${ }^{24}$

\section{Etika Islam dan Pencegahan Kecurangan}

Beekun mendefinisikan etika sebagai 'seperangkat prinsip atau pedoman moral yang membedakan yang baik dari yang buruk. ${ }^{25}$ Aturanaturan Islam yang digariskan dalam Quran dan hadits merupakan sumber etika yang dimaksudkan sebagai pedoman dalam tindakan manusia untuk memelihara kemaslahatannya. Islam sebagai agama yang universal menjadi sumber etika yang lengkap dan menyeluruh bagi manusia dalam beraktivitas di berbagai aspek kehidupan tak terkecuali dalam penggunaan aset dan keuangan di organisasi. Manakala moralitas individu sejalan dengan etika Islam dan dijalankan maka hal ini dapat mencegah ataupun meminimalkan terjadinya kasus-kasus kecurangan akuntansi.

Ajaran Islam memuat banyak terma terkait moralitas. Hal ini mencakup khair (kebaikan), birr (kebajikan), qist (persamaan), 'adl (keadilan), haqq (kejujuran dan kebenaran), ma'ruf (dapat diterima), dan taqwa (kesalehan). Islam memandang bahwa kerja merupakan keutamaan, karena kerja mengekspresikan nilai-nilai kejujuran, kehalalan hasil, ihsan (kesesuaian), efisien, pengendalian diri, pemenuhan kewajiban, ketaatan, kerjasama, disiplin dan tepat waktu, kehormatan, keadilan, perlindungan,

\footnotetext{
${ }^{22}$ Siti Sara Ibrahim, Norajila Che Man and Abd Halim Mohd Noor, Fraud: An Islamic Perspective,

The $5^{\text {th }}$ International Conference on Financial Criminology (ICFC 2013), "Global Trends in Financial Crimes in the New Economies". p.452.

${ }^{23}$ Musnad Ahmad nomor hadits 21365.

${ }^{24}$ Tulus Suryanto dan Anip Dwi Saputro, "Konsep Pencegahan Kecurangan..............".

${ }^{25}$ Rafik Issa Beekun, Etika Bisnis Islami, Penerjemah: Muhammad, Yogyakarta: Pustaka Pelajar 2004, hlm. 3.
} 
penjagaan hak, tanggung jawab, pertanggungjawaban, kemanusiaan, musyawarah/konsultasi, daya upaya, kompetisi, transparansi dan teamwork. ${ }^{26}$

\section{METODE}

Guna mengetahui faktor-faktor penyebab kecurangan akuntansi di lingkungan pemerintah daerah, studi ini mengumpulkan dan membandingkan hasil dari berbagai studi kuantitatif empiris di berbagai pemerintah daerah seluruh Indonesia yang dilakukan dalam rentang waktu tiga tahun terakhir (2015-2017). Hasil studi terdahulu merupakan data yang akan disintesakan dan ditarik kesimpulannya dalam studi ini guna menjawab pertanyaan-pertanyaan penelitian tersebut diatas. Data tersebut diperoleh dalam jurnal yang ditelusuri dalam beberapa media elektronik seperti digital library, internet ataupun koleksi jurnal perpustakaan. Kata kunci yang digunakan untuk penelusuran adalah: faktor-faktor kecurangan akuntansi, fraud, pencegahan kecurangan dan pemerintah daerah.

\section{PEMBAHASAN}

\section{Lokasi dan Subyek Penelitian}

Penelitian ini mengumpulkan hasil-hasil studi mengenai faktor-faktor kecurangan akuntansi di berbagai wilayah pemerintahan daerah seluruh Indonesia. Dari penelusuran literatur terdahulu ditemukan sejumlah 47 studi kuantitatif inferensial mengenai determinan kecurangan akuntansi di pemerintah daerah dalam kurun tahun 2015 - 2017.

Tabel 1. Lokasi Penelitian Terdahulu mengenai Faktor-Faktor Kecurangan Akuntansi di Pemerintah Daerah

\begin{tabular}{|l|c|l|}
\hline \multicolumn{1}{|c|}{ Peneliti } & Tahun & \multicolumn{1}{c|}{ Lokasi } \\
\hline $\begin{array}{l}\text { GK Saputra, NAS Darmawan dan IGA } \\
\text { Purnamawati }\end{array}$ & 2015 & Buleleng, Bali \\
\hline RF Amanda & 2015 & Padang Panjang, Sumbar \\
\hline RSK Karo & 2015 & Bandung, Jabar \\
\hline Adinda dan Ikhsan & 2015 & Klaten, Jateng \\
\hline
\end{tabular}

${ }^{26}$ Ahmad Saiful Azlin Puteh Salin and others, 'The Role of Islamic Ethics to Prevent Corporate

Fraud', International Journal of Business and Society, 2017.Vol 18, S1, pp.113-128, p.122. 


\begin{tabular}{|c|c|c|}
\hline Peneliti & Tahun & Lokasi \\
\hline Syamsul Hadi dan MPD Prasaja & 2015 & Sragen, Jateng \\
\hline PSNL Putu, GA Yuniarta dan IMP Adiputra & 2015 & Tabanan, Bali \\
\hline Ahriati, Basuki dan Widiastuty & 2015 & Lombok Timur \\
\hline Eliza & 2015 & Padang, Sumbar \\
\hline Chandra dan Ikhsan & 2015 & Grobogan, Jateng \\
\hline Amalia, Kamaliah dan Idrus & 2015 & Siak, Riau \\
\hline Safitri, Hasan dan Fachrunisa & 2015 & Kampar, Riau \\
\hline Aliyudin & 2015 & Indramayu, Jabar \\
\hline Noviriantini, Darmawan dan Werastuti & 2015 & Jembrana, Bali \\
\hline Arifianti, Santoso, Handajani & 2016 & Propinsi NTB \\
\hline TE Saputra, Andreas dan Anisma & 2016 & Bintan, Riau \\
\hline Mhd. Rizky Indra & 2016 & Pekanbaru, Riau \\
\hline Liliani Widia Saputri & 2016 & Buleleng, Bali \\
\hline Adrian Bartenputra & 2016 & Bukittinggi, Sumbar \\
\hline Riris Karisma Kholid & 2016 & Propinsi Lampung \\
\hline Devy Ervina Indriastuti, Agusdin, Animah & 2016 & Lombok, NTB \\
\hline Laurensia $\mathrm{Br}$ Tarigan & 2016 & Propinsi Riau \\
\hline Eni Shofiani & 2016 & Kudus, Jateng \\
\hline Rani Suryaningtyas & 2016 & Temanggung, Jateng \\
\hline Eni Mukaromah & 2016 & Jawa tengah \\
\hline Ratmono dan Pradopowati & 2016 & Jawa Tengah. \\
\hline KSD Yuda, NLGE Sulindawati, MA Wahyuni & 2016 & Klungkung, Bali \\
\hline Dedi Fafanto & 2016 & Provinsi Bali \\
\hline Delima Suma Bestari & 2016 & Propinsi Riau \\
\hline Wenny Ardiana & 2016 & Kota Surakarta, Jateng \\
\hline KTK Dewi, MA Wahyuni dan NT Herawati & 2017 & Kab. Buleleng Bali \\
\hline Ni Komang Linda Lestari, Ni Luh Supadmi & 2017 & Kab Klungkung Bali \\
\hline CKR Dewi, RAS Surya dan MA Hasan & 2017 & Kab Bengkalis, Riau \\
\hline Taufik Sulaksono Kurrohman & 2017 & Kab Jember, Jatim \\
\hline Afri Ade & 2017 & Kab Tanah Datar, Sumbar \\
\hline GAKRS Dewi & 2017 & Propinsi Bali \\
\hline Syahriani Usman & 2017 & Kab. Luwu timur, Sulsel \\
\hline AN Downida dan Ikhsan Budi Riharjo & 2017 & Kota Kediri, Jatim \\
\hline Siti Fitriani Afsari & 2017 & Kab Jember, Jatim \\
\hline Rizky Rahmadha, Sukirno Sukirno & 2017 & Kota Magelang, Jateng \\
\hline Herlina Tri Astuti & 2017 & Propinsi Kepulauan Riau \\
\hline $\begin{array}{l}\text { Moh.Risqi Kurnia Adi, Komala Ardiyani, Arum } \\
\text { Ardianingsih. }\end{array}$ & 2017 & Kota Pekalongan, Jateng \\
\hline Gilang Noor Alamsyah & 2017 & Kota Bandung, Jabar \\
\hline
\end{tabular}




\begin{tabular}{|l|c|l|}
\hline \multicolumn{1}{|c|}{ Peneliti } & Tahun & \multicolumn{1}{c|}{ Lokasi } \\
\hline U. Ari Alrizwan & 2017 & Pemda Sambas KalBar \\
\hline Wulandari dan Suryandari & 2017 & Temanggung, Jateng \\
\hline Afidatul Lailiyah & 2017 & Kab. Situbondo, Jatim \\
\hline Fatimatuzzahroh & 2017 & Kota Semarang, Jateng \\
\hline $\begin{array}{l}\text { Afrilia Fitri Wulandari, Anita Wijayanti, Yuli } \\
\text { Chomsatu Samrotun. }\end{array}$ & 2017 & Kab Sragen, Jateng \\
\hline
\end{tabular}

Lokasi studi-studi tersebut cukup menyebar di berbagai propinsi. Penelitian terbanyak dilakukan di propinsi Jawa tengah (13 studi), diikuti Bali (9 studi) dan Riau (8 studi). Propinsi Sumater Barat dan Jawa timur masing-masing 4 studi, propinsi NTB dan Jawa barat masing-masing 3 dan selebihnya propinsi Lampung, Sulawesi selatan dan Kalimantan barat masingmasing 1 studi.

Gambar 1. Grafik Sebaran Lokasi Penelitian Terdahulu mengenai Faktorfaktor Kecurangan Akuntansi di Pemerintah Daerah

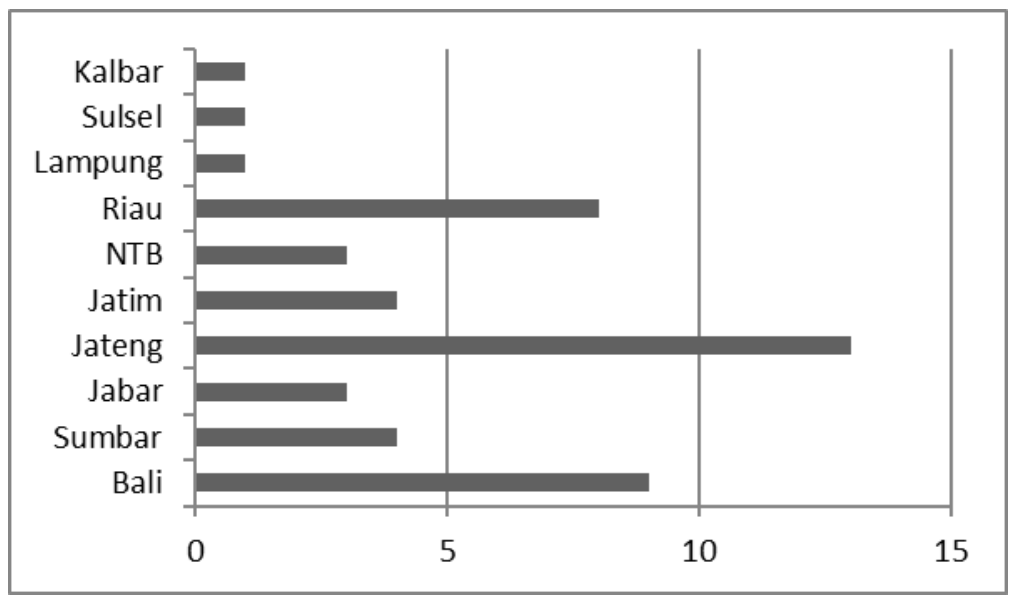

Studi-studi kecurangan di lingkungan pemerintah daerah pada umumnya mengumpulkan data melalui metode survey persepsi responden dalam hal ini adalah para pegawai di Satuan Kerja Perangkat Daerah (SKPD) dan di Badan Usaha Milik Daerah (BUMD). Pegawai yang dipilih sebagai responden khususnya yang bidang kerjanya terkait dengan aktivitas 
akuntansi, pengelolaan aset dan pengadaan barang/jasa.Teknik sampling yang digunakan sebagian besar menggunakan teknik purposive sampling.

\section{Faktor-faktor Kecurangan Akuntansi di Pemerintah Daerah}

Variabel kecurangan akuntansi sulit untuk diukur secara langsung. sehingga studi-studi empiris umumnya menggunakan kecenderungan kecurangan sebagai variabel proksi. Kecenderungan kecurangan diukur menggunakan penilaian kuisioner, pada umumnya mencakup 5 indikator: 1) kecenderungan memanipulasi atau memalsu atau merubah catatan akuntansi dan atau dokumen pendukungnya, 2) kecenderungan menyajikan secara salah atau menghilangkan peristiwa, transaksi, atau informasi yang signifikan dari laporan keuangan, 3) kecenderungan salah menerapkan prinsip akuntansi secara sengaja, 4) kecenderungan menyajikan laporan keuangan yang salah akibat pencurian (penyalahgunaan/penggelapan) terhadap aktiva yang membuat entitas membayar barang/jasa yang tidak diterima, 5)kecenderungan menyajikan laporan keuangan yang salah akibat perlakuan yang tidak semestinya terhadap aktiva yang disertai dengan catatan atau dokumen palsu dan dapat menyangkut satu atau lebih individu diantara manajemen, karyawan atau pihak ketiga.

Tabel 2. Variabel Operasional Penelitian Terdahulu mengenai Faktor-Faktor Kecurangan Akuntansi di Pemerintah Daerah

\begin{tabular}{|c|c|c|c|}
\hline Tekanan & Kesempatan & Rasionalisasi & Kapabilitas \\
\hline $\begin{array}{ll}\text { - } & \text { Kepuasan } \\
\text { kompensasi } \\
\text { - Keadilan } \\
\text { oganisasi } \\
\text { (prosedural, } \\
\text { distributif) } \\
\text { - Tekanan } \\
\text { situasional: } \\
\text { Superioritas } \\
\text { otoritas, gaya } \\
\text { kepemimpinan }\end{array}$ & 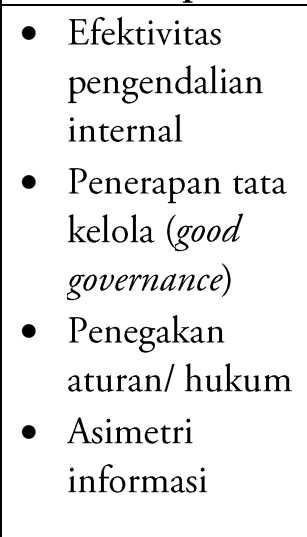 & $\begin{array}{l}\text { - } \begin{array}{l}\text { Budaya etis } \\
\text { organisasi }\end{array} \\
\text { - Komitmen } \\
\text { organisasi }\end{array}$ & 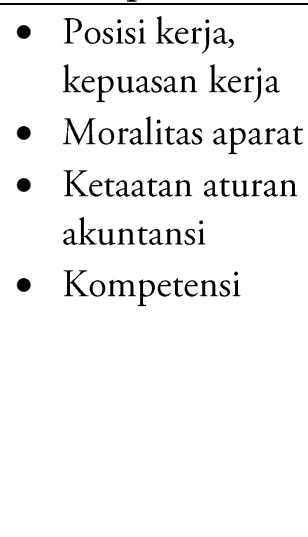 \\
\hline
\end{tabular}


Berdasarkan teori Fraud Triangle dan Fraud Diamond, ada empat elemen yang dapat mempengaruhi terjadinya kecurangan akuntansi yaitu Tekanan (pressure), Kesempatan (opportunity), Rasionalisasi (Rationalization), dan Kapabilitas (capability). Dalam studi empiris, keempat elemen tersebut dijabarkan lebih lanjut dalam berbagai variabel-variabel operasional. Tabel 2 mengumpulkan berbagai variabel dari keempat elemen dalam teori Fraud yang digunakan dalam berbagai studi terdahulu yang terbukti efektif dapat menekan atau mencegah kecurangan akuntansi di berbagai pemerintah daerah. Kaitan antara tiap faktor dengan kecurangan akuntansi dijelaskan dalam alinea selanjutnya.

Studi empiris membuktikan bahwa keadilan perlakuan dalam organisasi yang bersifat prosedural maupun distributif termasuk di dalamnya pemberian kompensasi pegawai merupakan faktor yang mendorong pegawai berlaku curang. Menurut Veitzhal Rivai kompensasi merupakan 'sesuatu yang diterima karyawan sebagai pengganti kontribusi jasa mereka pada perusahaan. ${ }^{27}$ Bentuknya dapat berupa uang dan barang langsung atau tidak langsung yang diterima karyawan sebagai imbalan atas jasa yang diberikan oleh perusahaan. ${ }^{28}$ Pemberian kompensasi yang memuaskan menurut pegawai diharapkan dapat mencegah mereka berlaku curang untuk keuntungan pribadi.

Gaya kepemimpinan juga dapat menjadi faktor penekan munculnya kecurangan oleh pegawai. Menurut Tjiptono gaya kepemimpinan adalah 'suatu cara yang digunakan pemimpin dalam berinteraksi dengan bawahannya. ${ }^{29}$ Gaya kepemimpinan menurut Hersey mencakup pola tingkah laku berupa tindakan dan kata-kata seorang pemimpin yang dirasakan oleh orang lain. ${ }^{30}$ Tingkah laku ini digunakan pemimpin dalam mempengaruhi pikiran, perasaan, sikap dan perilaku para anggota organisasi bawahannya. ${ }^{31}$ Studi membuktikan bahwa gaya kepemimpinan yang otoriter cenderung dapat menyuburkan kecurangan. Sebaliknya kepemimpinan yang demokratis dapat meminimalkan kecenderungan pegawai melakukan kecurangan akuntansi.

\footnotetext{
${ }^{27}$ Veithzal Rivai, Manajemen Sumber Daya Manusia untuk Perusahaan,: dari Teori ke Praktek. Jakarta: Rajagrafindo Persada, 2004, hlm. 357.

${ }^{28}$ Malayu S.P. Hasibuan, Manajemen Dasar, Pengertian dan Masalah. Jakarta: Bumi Aksara, 2006, hlm. 133.

${ }^{29}$ Fandy Tjiptono, Manajemen Pelayanan Jasa, Yogyakarta: Penerbit Andi, 2006, hlm 161.

${ }^{30}$ Hersey, Kunci Sukses Pemimpin Situasional. Jakarta: Delaprasata, 2004, hlm.29.

${ }^{31}$ Hadari Nawawi, Kepemimpinan, Mengefektifkan Organisasi. Yogyakarta: Gajah Mada University Press, 2003, hlm.115.
} 
Studi terdahulu juga mengidentifikasi faktor-faktor yang menyuburkan kesempatan atau peluang kecurangan akuntansi yaitu lemahnya pengendalian internal dan tata kelola serta penegakan aturan. Pengendalian internal dalam arti luas merupakan berbagai alat manajemen untuk melakukan pengawasan. Boynton and Johnson menjelaskan pengendalian internal sebagai proses yang dipengaruhi oleh dewan entitas direksi, dan personel lainnya yang dirancang untuk memberikan keyakinan tentang pencapaian tujuan yaitu keandalan pelaporan keuangan, kepatuhan hukum dan peraturan, efektivitas serta efisiensi operasi. ${ }^{32}$ Pengendalian internal dan tata kelola yang lemah membuat tujuan-tujuan tersebut lebih sulit direalisasikan. Hal ini akan diperparah dengan penegakan aturan yang lemah dalam organisasi.

Lebarnya kesenjangan (asimetri informasi) antara pimpinan dan pegawai juga memberi ruang subur kecurangan akuntansi. Asimetri informasi dijelaskan dalam Supriyono, merupakan suatu keadaan dimana informasi yang dimiliki bawahan melebihi informasi yang dimiliki atasannya. ${ }^{33}$ Kondisi ini rawan membuat pegawai memanfaatkan situasi untuk kepentingan pribadinya yang merugikan organisasi. Misalnya dengan memanipulasi informasi keuangan yang dilaporkan atau memberikan informasi yang menyesatkan.

Rasionalisasi atau pembenaran pegawai atas perilaku curang yang dilakukannya dapat terjadi karena kesenjangan integritas pribadi pegawai atau pertimbangan moral yang lain. ${ }^{34}$ Komitmen terhadap organisasi dan faktor lingkungan internal seperti budaya organisasi dapat menjadi sumber rasionalisasi. Menurut Rae and Subramanyam, komitmen organisasi secara umum merupakan sikap-sikap dan perasaan karyawan yang berhubungan dengan nilai-nilai dan cara perusahaan melakukan berbagai hal, termasuk dalam tindakan kecurangan. ${ }^{35}$ Semakin tinggi komitmen organisasi, akan semakin rendah kecurangan terjadi. Budaya organisasi dapat diartikan sebagai

\footnotetext{
${ }^{32}$ Boynton and Johnson, Modern Auditing, $8^{\text {th }}$ Edition, New York: John Willey and Sons Inc, 2006, p.323.

${ }^{33}$ Supriyono, 'Pengaruh Komitmen Organisasi Dan Keinginan Sosial Terhadap Hubungan Antara Partisipasi Penganggaran Dengan Kinerja Manajer', Jurnal Ekonomi Dan Bisnis Indonesia, 2004, Vol. 20, No. 1, 20-56, hlm.41.

${ }^{34}$ Aditya Pramudita, 'Analisis Fraud Di Sektor Pemerintahan Kota Salatiga', Accounting Analysis Journal, 2013, Vol. 1 (2), 2013, hlm.36.

${ }^{35}$ Kirsty Rae and Nava Subramaniam, 'Quality of Internal Control Procedures: Antecedents and Moderating Effect on Organisational Justice and Employee Fraud', Managerial Auditing Journal, 2008, Vol. 23 No. 2, pp. 104-124.
} 
sistem Budaya organisasi menurut Wood dan kawan-kawan dapat diartikan sebagai sistem yang dipercayai dan nilai yang dikembangkan oleh organisasi dimana hal itu menuntun perilaku anggota organisasi itu sendiri. ${ }^{36}$ Isu dan kekuatan budaya mempengaruhi suasana etis organisasi dan perilaku para anggotanya.

Menurut Wolfe dan Hermanson seseorang melakukan kecurangan tentu memiliki kapabilitas untuk melakukannya, dimana dia menyadari ada peluang dan memanfaatkannya bukan hanya sekali namun berkali-kali. Oleh karenanya suatu sistem deteksi sangat penting untuk mempertimbangkan kemampuan personal yang ada di perusahaan melakukan fraud. Variabelvariabel kapabilitas yang terbukti mempengaruhi perilaku curang pegawai di pemerintahan daerah adalah kepuasan kerja, moralitas aparat, ketaatan akuntansi dan kompetensi.

Kepuasan kerja dijelaskan oleh Robbins dan Timothy sebagai suatu sikap umum terhadap pekerjaan seseorang, selisih antara banyaknya ganjaran yang diterima seseorang pekerja dan banyak yang mereka yakini seharusnya mereka terima. ${ }^{37}$ Studi empiris membuktikan kepuasan kerja pegawai pemerintahan berpengaruh signifikan terhadap kecenderungan berbuat curang. Rivai dalam studinya menyatakan bahwa kepuasan kerja berpengaruh terhadap kecurangan, akibat ketidakpuasan kerja akan mengurangi kinerja, meningkatkan keluhan, mogok kerja dan mengarah kepada tindakantindakan fisik dan psikologis seperti meningkatkan derajat ketidakhadiran dan kecurangan. ${ }^{38}$ Menurut Parasmita Ayu Putri dalam penelitiannya, kepuasan kerja memiliki dampak pada perilaku, dimana karyawan yang kepuasan kerja tingginya akan berperilaku positif terhadap pekerjaannya dan diharapkan karyawan tersebut jauh dari perilaku kecurangan Akuntansi. ${ }^{39}$

Moralitas aparat juga mempengaruhi kapabilitasnya melakukan fraud. Moralitas adalah tekad untuk mengikuti apa yang ada dalam hati manusia

\footnotetext{
${ }^{36}$ Wood et.al., Organizational Behavior a Global Perspective, Australia: John Wiley and Sons, p.391.

${ }^{37}$ Robbins dan Timothy, Perilaku Organisasi, Jakarta: Salemba Empat,2008, hlm.110.

38 Veithzal Rivai, Manajemen Sumber Daya Manusia untuk Perusahaan,: dari Teori ke Praktek. Jakarta: Rajagrafindo Persada, 2004, hlm. 74.

${ }^{39}$ Ananda Aprishella Parasmita Ayu Putri, 'Pengaruh Keefektifan Pengendalian Internal Dan Kepuasan Kerja Terhadap Kecenderungan Kecurangan Akuntansi Pada Dinas Pendapatan Pengelolaan Keuangan Aset Daerah Istimewa Yogyakarta', Nominal: Barometer Riset Akuntansi Dan Manajemen, 2014, Vol. III nomor 1, 2014.
} 
dan disadari sebagai kewajiban mutlak. ${ }^{40}$ Moralitas dapat melahirkan ketaatan, termasuk ketaatan terhadap aturan akuntansi dan hal ini akan berdampak terhadap minimalnya pelanggaran atau kecurangan.

Untuk mencegah ataupun mendeteksi adanya kecurangan, diperlukan kompetensi sumber daya manusia. Kompetensi sumber daya manusia merupakan kemampuan seseorang, suatu organisasi atau lembaga atau sistem untuk melaksanakan fungsi-fungsi atau kewenangannya untuk mencapai tujuannya secara efektif dan efisien. ${ }^{41}$ Dalam kaitannya dengan pekerjaan akuntansi, kompetensi terkait dengan kemampuan teknis pegawai dalam menjalankan sistem akuntansi hingga pada pelaporan keuangannya. Dalam kaitannya dengan pendeteksian kecurangan akuntansi, kompetensi ini menyangkut kualifikasi auditor untuk melaksanakan audit dengan benar, diantaranya kepribadian yang baik, pengetahuan memadai serta keahlian khusus di bidangnya.

\section{Pencegahan dan Penanganan kecurangan akuntansi dalam Perspektif Islam Peran Etika Islam}

Cressey, ${ }^{42}$ Haron et.al., ${ }^{43}$ dan banyak ahli kecurangan lainnya meyakini bahwa adanya nilai-nilai etika dan kepatuhan pegawai terhadap nilai-nilai tersebut dapat mengurangi terjadinya perilaku curang di organisasi. Contoh yang paling nyata adalah kasus Enron, Zandstra menyatakan kecurangan besar di Enron terjadi utamanya karena absennya tanggung jawab etis dari karyawannya. ${ }^{44}$

Nilai-nilai etis dapat dibangun dan dikuatkan melalui seperangkat kode etik, training, dukungan manajemen puncak, kepatuhan, dan program

\footnotetext{
${ }^{40}$ Petra Zulia Aranta, 'Pengaruh Moralitas Aparat Dan Asimetri Informasi Terhadap Kecenderungan Kecurangan Akuntansi (Studi Empiris Pemerintah Kota Sawahlunto)', Jurnal Akuntansi, 2013, hlm.7.

${ }^{41}$ Syifa Nurillah dan Dul Muid, "Pengaruh Kompetensi Sumber Daya Manusia, Penerapan Sistem Akuntansi Keuangan Daerah (SAKD), Pemanfaatan Teknologi Informasi, dan Sistem Pengendalian Intern terhadap Kualitas Laporan Keuangan Pemerintah Daerah”, Diponegoro Journal of Accounting, vol.1 nomor 1, hlm. 2.

${ }^{42}$ Donald R. Cressey, 'Other People's Money: A Study ..... pp.362-363.

${ }^{43}$ Hasnah Haron, Ishak Ismail, and shaikh hamzah Abdul razak, 'Factors Influencing Unethical Behavior of Insurance Agents', International Journal of Business and Social Science, 2011, 2(1), pp. $1-17$.

${ }^{44}$ Gerald Zandstra, 'Enron, Board Governance and Moral Failings', Corporate Governance: The International Journal of Business in Society, 2002, .2(2), pp.16-19.
} 
etika khusus lainnya seperti layanan cepat (hotline), kelompok etik, dan penunjukkan satgas etika. ${ }^{45}$ Salah satu sumber etika bisa berasal dari ajaran agama, dalam hal ini Islam.

Beberapa studi empiris telah membuktikan peran etika Islam ataupun etika bisnis Islam terhadap kecurangan di berbagai organisasi. Shinta Maharani misalnya, dalam studinya mengungkap bahwa penerapan etika bisnis Islam mempengaruhi secara signifikan terhadap pencegahan penipuan dalam pelaporan keuangan di badan publik di Indonesia. ${ }^{46}$ Hamdani mengkaji pengaruh etika kerja Islami terhadap internal fraud di koperasi syariah. Studinya membuktikan bahwa implementasi etika kerja Islami mampu menurunkan hasrat seseorang untuk melakukan internal fraud. ${ }^{47}$ Studi di lingkup pemerintahan oleh Deyanira Safitri juga mengungkap bahwa faktor religiusitas berdampak positif dan signifikan dalam mencegah terjadinya kecurangan. ${ }^{48}$

\section{E. KESIMPULAN}

Studi ini telah mengidentifikasi berbagai faktor yang mempengaruhi kecurangan di pemerintah daerah. Faktor-faktor yang menjadi sumber tekanan bagi munculnya kecurangan adalah kepuasan kompensasi, keadilan organisasi dan gaya kepemimpinan. Adapun sumber-sumber peluang kecurangan terletak pada keefektifan pengendalian internal dan tata kelola (good governance), penegakan aturan/ hukum dan tingkat asimetri informasi yang terjadi. Faktor pendukung terjadinya rasionalisasi kecurangan adalah budaya etis dan komitmen organisasi. Adapun faktor kapabilitas ditentukan oleh kepuasan kerja, moralitas dan ketaatan aparat terhadap aturan akuntansi serta kompetensinya.

\footnotetext{
${ }^{45}$ Nicole Andreoli and Joel Lefkowitz, 'Individual and Organizational Antecedents of Misconduct in Organizations', Journal of Business Ethics, 2009, 85(3), 2009, pp. 309-332.

${ }^{46}$ Shinta Maharani, 'Pengaruh Etika Bisnis Islam Terhadap Kencenderungan Kecurangan Akuntansi Dalam Pelaporan Keuangan Entitas Publik Di Indonesia', IJTIHAD Jurnal Hukum dan Ekonomi Islam, Vol 7, No 2 (2013).

${ }^{47}$ Hamdani, Pengaruh Etika Kerja Islami dan Sistem Pengendalian Internal terhadap Internal Fraud serta Implikasinya pada Reputasi Koperasi KPP UMKM Syariah. Tesis pada Program Magister Akuntansi Universitas Esa Unggul, 2016.

${ }^{48}$ Deyanira Safitri, Pengaruh Religiusitas dan Komitmen Profesional terhadap Upaya Pencegahan Fraud di Pemerintahan, Skripsi pada Universitas Airlangga Surabaya, 2017.
} 
Berdasarkan studi literatur ditemukan pula bahwa pelaksanaan etika Islam dapat mencegah kecurangan di organisasi. oleh karena itu, untuk mencegah dan meminimalkan kecurangan di pemerintah daerah dapat dilakukan perbaikan terhadap faktor-faktor di atas termasuk juga mengembangkan budaya etika yang sejalan dengan nilai-nilai Islam.

\section{DAFTAR PUSTAKA}

Abdul Halim dkk., 2012. Akuntansi Sektor Publik Akuntansi Keuangan Daerah. Edisi 4. Jakarta: Penerbit Salemba Empat.

Abdullahi, R, and N Mansor, 2015. 'Fraud Triangle Theory and Fraud Diamond Theory: Understanding the Convergent and Divergent For Future Research', International Journal of Academic Research in Accounting, Finance and Management Sciences, Vol 5 No 4.

ACFE, Indonesia Chapter, 2016. 'Survai Fraud Indonesia 2016', ACFE Association of Certified Fraud Examiners.

Andreoli, Nicole, and Joel Lefkowitz, 2009. 'Individual and Organizational Antecedents of Misconduct in Organizations', Journal of Business Ethics, vol 85, issue 3, pp.309-332.

Aranta, Petra Zulia, 2013. 'Pengaruh Moralitas Aparat Dan Asimetri Informasi Terhadap Kecenderungan Kecurangan Akuntansi (Studi Empiris Pemerintah Kota Sawahlunto)', Skripsi, Universitas Negeri Padang.

Beekun, Rafik Issa, 2004, Etika Bisnis Islami, Penerjemah: Muhammad, Yogyakarta: Pustaka Pelajar.

Boynton, William C., Raymond N. Johnson., 2006, "Modern Auditing”, 8Th Edition, New York: John Willey \& Sons Inc.

Cressey, Donald R., 1954. 'Other People's Money: A Study in the Social Psychology of Embezzlement.', American Sociological Review, 19 (3).

Hall, James A., 'Accounting Information Systems Seventh Edition', in SouthWestern Cengagae Learning, 2011.

Hamdani, 2016, Pengaruh Etika Kerja Islami dan Sistem Pengendalian Internal terhadap Internal Fraud serta Implikasinya pada Reputasi Koperasi KPP UMKM Syariah. Tesis pada Program Magister Akuntansi Universitas Esa Unggul.

Haron, Hasnah, Ishak Ismail, and shaikh hamzah Abdul razak, 2011. 'Factors Influencing Unethical Behavior of Insurance Agents', International 
Journal of Business and Social Science, vol 2, no. 1.

Hasibuan, Malayu S. P., 2006, Manajemen Dasar, Pengertian dan Masalah. Jakarta: Bumi Aksara.

Hersey, 2004, Kunci Sukses Pemimpin Situasional. Jakarta: Delaprasata. http://news.liputan6.com/read/2477341/kasus-korupsi-di-indonesiamenggila.

http://www.acfe.com/fraud-triangle.aspx the fraud triangle.

https://kominfo.go.id/index.php/content/detail/6547/Potret-Buram-KorupsiIndonesia/0/infografis.

https://www.transparency.org/news/feature/corruption_perceptions_index_2 017 ,

James A. Hall, 2012. Accounting Information System, $8^{\text {th }}$ Edition, South Western: Cengage Learning.

Karni, Soejono, 2000. Auditing, Audit Khusus dan Audit Forensik, Jakarta: Lembaga Penerbit FE UI.

Karyono, Forensic Fraud, Yogyakarta: Penerbit ANDI, 2013, hlm. 3.

Maharani, Shinta., 2013, Pengaruh Etika Bisnis Islam terhadap Kecenderungan Kecurangan Akuntansi dalam Pelaporan Keuangan pada Entitas Publik di Indonesia, IJTIHAD Jurnal Hukum dan Ekonomi Islam, Vol 7, No 2.

Nawawi, Hadari. 2003. Kepemimpinan Mengefektifkan Organisasi. Yogyakarta: Gajah Mada University Press.

Nurillah, Syifa dan Dul Muid. 2014. Pengaruh Kompetensi Sumber Daya Manusia, Penerapan Sistem Akuntansi Keuangan Daerah (SAKD), Pemanfaatan Teknologi Informasi, Dan Sistem Pengendalian Intern Terhadap Kualitas Laporan Keuangan Pemerintah Daerah, Diponegoro Journal of Accounting, Volume 1, Nomor 1.

Pramudita, Aditya, 2013. 'Analisis Fraud Di Sektor Pemerintahan Kota Salatiga', Accounting Analysis Journal, Vol. 1 (2).

Putri, Ananda Aprishella Parasmita Ayu, 2014. 'Pengaruh Keefektifan

Pengendalian Internal Dan Kepuasan Kerja Terhadap Kecenderungan Kecurangan Akuntansi Pada Dinas Pendapatan Pengelolaan Keuangan Aset Daerah Istimewa Yogyakarta', Nominal: Barometer Riset Akuntansi Dan Manajemen, Vol 3, No 1.

Rae, Kirsty, and Nava Subramaniam, 2008. 'Quality of Internal Control Procedures: Antecedents and Moderating Effect on Organisational Justice and Employee Fraud', Managerial Auditing Journal, Vol. 23 No. 2. pp. 104-124. 
Rival, Veithzal. 2004. Manajemen Sumber Daya Manusia untuk Perusahaan: Dari Teori ke Praktek. Jakarta: Rajagrafindo Persada.

Robbins, Stephen P., Judge, Timothy A., 2008. Perilaku Organisasi. Salemba Empat, Jakarta.

Salin, Ahmad Saiful Azlin Puteh, Siti Khadijah Ab Manan, Norlela Kamaluddin, and Anuar Nawawi, 2017. 'The Role of Islamic Ethics to Prevent Corporate Fraud', International Journal of Business and Society, Vol. 18 S1.

Supriyono, R.A., 2004. 'Pengaruh Komitmen Organisasi Dan Keinginan Sosial Terhadap Hubungan Antara Partisipasi Penganggaran Dengan Kinerja Manajer', Jurnal Ekonomi Dan BIsnis Indonesia, vol 20, no 1.

Safitri, Deyanira, 2017., Pengaruh Religiusitas dan Komitmen Profesional terhadap Upaya Pencegahan Fraud di Pemerintahan, Skripsi pada Universitas Airlangga Surabaya.

Siti Sara Ibrahim, Norajila Che Man and Abd Halim Mohd Noor, 2013. Fraud: An Islamic Perspective, The $5^{\text {th }}$ International Conference on Financial Criminology (ICFC 2013), "Global Trends in Financial Crimes in the New Economies".

Suryanto, Tulus, and Anip Dwi Saputro, 2016. Fraud AKuntansi dalam Perspektif Islam, Yogyakarta: CV. Arti Bumi Intaran.

Tjiptono, Fandy, 2006, Manajemen Pelayanan Jasa, Yogyakarta: Penerbit Andi.

Tuanakotta, Theodorus M., 2007. Akuntansi Forensik dan Audit Investigatif. Jakarta : Lembaga Penerbit Fakultas Ekonomi Universitas Indonesia.

Empat.

Wood, Wallace, Zeffane, Schermerhorn, Hunt, and Osborn. 2001. Organizational Behavior A Global Perspective. John Wiley \&Sons. Australia.

Zandstra, Gerald, 2002. 'Enron, Board Governance and Moral Failings', Corporate Governance: The International Journal of Business in Society, vol 2, issue 2, pp.16-19. 